\title{
HUBUNGAN ANTARA NELAYAN JEPARA DAN KARIMUNJAWA DALAM MEMANFAATKAN SUMBERDAYA PERIKANAN DI TAMAN NASIONAL KARIMUNJAWA
}

\author{
Relationhip between Fishers in Jepara and Karimunjawa to Use Fisheries Resource in \\ Karimunjawa Nasional Park
}

\author{
Fevrina Leny Tampubolon*) dan Arif Satria
}

Departemen Sains Komunikasi dan Pengembangan Masyarakat, Fakultas Ekologi Manusia, IPB

\begin{abstract}
The objectives of this research are: (1) to find, identify, and analyze fisheries resource management by National Park Karimunjawa and Local Government Jepara; (2) to identify, and analyze social bridging capital between fishers in Karimunjawa and fishers in Jepara; (3) to find, identify, and analyze the relationship between social capital and perception of conflict between fishers in Karimunjawa and fishers in Jepara. Bridging social capital consists of three aspects, the network outside the community, the participation and membership in groups outside the community, and the level of trust to the outside community. The research shows that there is a relationship between bridging social capital and perception of conflict. The low bridging social capital between fishers in Karimunjawa and Jepara cause high perception of conflict among the fisher.
\end{abstract}

Keywords: bridging social capital, conflict, fisheries management National Park

\begin{abstract}
ABSTRAK
Tujuan dari penelitian ini adalah (1) untuk mengetahui, mengidentifikasi, dan menganalisis pengelolaan sumberdaya perikanan oleh Taman Nasional Karimunjawa dan Pemerintah Lokal Jepara; (2) untuk mengidentifikasi dan menganalisis modal sosial menyambung antara nelayan di Karimunjawa dan Jepara; (3) untuk mengetahui, mengidentifikasi, dan menganalisis hubungan antara modal sosial dan pandangan konflik antara nelayan di Karimunjawa dan Jepara. Modal sosial menyambung terdiri dari tiga aspek, jaringan diluar komunitas, keikutsertaan dan keanggotaan dalam kelompok diluar komunitas, dan tingkat kepercayaan terhadap komunitas luar. Penelitian menunjukkan bahwa terdapat hubungan antara modal sosial menyambung dan pandangan konflik. Rendahnya modal sosial menyambung antara nelayan Karimunjawa dan Jepara menyebabkan tingginya pandangan konflik diantara nelayan.
\end{abstract}

Kata kunci : konflik, modal sosial menyambung, pengelolaan perikanan Taman Nasional

\section{PENDAHULUAN}

Data pokok kelautan dan perikanan 2010 menggolongkan Indonesia sebagai negara kepulauan terbesar di dunia karena memiliki luas laut dan jumlah pulau yang banyak. Berdasarkan data indikator fisik Indonesia, luas lautan Indonesia seluas 3,56 juta km2. Indonesia memiliki panjang garis pantai mencapai $104.000 \mathrm{~km}$ dengan luas wilayah laut mendominasi total luas teritorial Indonesia. Berdasarkan data dari DKP (Departemen Kelautan dan Perikanan) 2007, Indonesia juga dikaruniai sekitar 3.000 jenis ikan di perairan laut dan tawar. Indonesia berada di wilayah pusat segitiga terumbu karang dunia sehingga memiliki berbagai jenis terumbu karang yang tersebar luas di seluruh wilayah Indonesia. Potensi tersebut menempatkan Indonesia sebagai negara yang dikaruniai sumberdaya kelautan yang besar termasuk kekayaan keanekaragaman hayati dan non hayati.

Luas lautan Indonesia yang mendominasi, menempatkan sumberdaya kelautan menjadi salah satu kekayaan alam yang banyak dimanfaatkan oleh masyarakat terutama dalam bidang perikanan. Pengelolaan dan pemanfaatan sumberdaya perikanan pada dasarnya bertujuan untuk meningkatkan kesejahteraan seluruh masyarakat terutama di daerah pesisir. Oleh karena itu, kelestariannya harus dipertahankan sebagai landasan utama untuk mencapai kesejahteraan tersebut. Akan tetapi, pada kenyataannya sampai saat ini pemanfaatan sumberdaya perikanan kurang memerhatikan kelestariannya. Sumberdaya hayati perikanan dan kelautan di Indonesia telah mengalami kerusakan yang sangat parah. Berdasarkan riset Coremap LIPI (Lembaga Ilmu Pengetahuan Indoesia) dan LAPAN (Lembaga Penerbangan dan Antariksa Nasional) akhir Tahun 2008, hampir sepertiga kondisi terumbu karang di Indonesia berkategori rusak.

Kerusakan juga terjadi di sektor perikanan dimana sumberdaya ikan telah terdegradasi yang menyebabkan menurunnya stok ikan. Hal ini disebabkan karena sebagian besar WPP (Wilayah Pengelolaan Perikanan) Indonesia telah dieksploitasi secara berlebihan (DKP 2007). Degradasi sumberdaya ikan disebabkan oleh pengelolaan sumberdaya yang tidak ramah lingkungan dengan menggunakan alat 
tangkap yang merusak kelestarian sumberdaya ikan. Apabila kondisi ini terus terjadi dapat dipastikan potensi sumberdaya perikanan akan semakin menurun.

Penurunan sumberdaya perikanan ternyata tidak diikuti dengan penurunan pemanfaatan sumberdaya perikanan seperti yang disebutkan dalam Kep 18/Men/2011 Pada tahun 2006-2007 jumlah nelayan naik terus, yaitu $2,06 \%$, sedangkan ikan makin langka. Penurunan potensi sumberdaya perikanan dan peningkatan jumlah nelayan dapat dipastikan akan meningkatkan persaingan di kalangan nelayan. Tidak menutup kemungkinan persaingan yang semakin ketat akan meningkatkan potensi konflik antar nelayan. Banyak pihak yang memiliki kepentingan dalam pemanfaatan sumberdaya alam bukan hanya masyarakat tetapi pemerintah bahkan swasta juga memiliki kepentingan.

Konservasi menjadi suatu desain pengelolaan yang komprehensif dalam rangka mengatasi degradasi sumber daya kelautan di Indonesia. Taman Nasional Laut adalah bentuk konservasi . Taman Nasional Karimunjawa adalah salah satu bentuk konservasi di Indonesia. Konservasi pada dasarnya adalah tindakan melindungi agar tercipta keberlangsungan atau keberlanjutan dari suatu sumberdaya. Penetapan zonasi dalam pemanfaatan sumberdaya perikanan merupakan salah satu tindakan konservasi yang dilakukan oleh Taman Nasional. Penetapan zonasi dilakukan sesuai dengan UU No.5 Tahun 1990.

Penetapan sistem zonasi dalam pemanfaatan sumberdaya perikanan menghadapi banyak kendala. Hal ini juga dialami oleh Taman Nasional Karimunjawa dalam mengelola sumberdaya perikanan di Karimunjawa. Produk hukum dan peraturan yang tidak sinergis merupakan salah satu kendalanya. Pemerintah daerah menggunakan Undang-Undang No.32 Tahun 2004 sesuai dengan peraturan otonomi daerah. Taman Nasional Karimunjawa menggunakan UU No.5 Tahun 1990 untuk mengelola sumberdaya perikanan sesuai dengan landasan hukum konservasi. Pengelolaan yang dilakukan oleh Pemerintah Daerah Jepara dan Balai Taman Nasional Karimunjawa menimbulkan kaburnya batas-batas wilayah pemanfaatan oleh nelayan karena masing-masing pihak menetapkan batas wilayah pemanfaatan perikanan. Kaburnya batasbatas pengelolaan akhirnya menimbulkan perebutan wilayah tangkap dan konflik dalam pemanfaatan kawasan perikanan.

Konflik tidak selalu terjadi karena permasalahan tersebut, seringkali konflik terjadi hanya disebabkan oleh kurangnya komunikasi antar komunitas nelayan dengan wilayah geografis dan identitas etnik yang berbeda sehingga aturan main seringkali dilanggar atau terjadi salah tafsir. Kejadian ini menggambarkan menipisnya jaringan antar komunitas nelayan yang memiliki wilayah geografis dan identitas etnik yang berbeda atau yang disebut juga bridging social capital (Grafton 2005; Satria 2009a).

Dalam mengelola sumberdaya perikanan diperlukan adanya modal sosial menyambung (bridging social capital) yang baik. Modal sosial menyambung diperlukan agar tercipta komunikasi yang baik antar nelayan. Komunikasi yang baik antar nelayan dapat mewujudkan kesejahteraan sosial antar nelayan apabila disertai dengan kinerja yang baik oleh pemerintah dalam membuat produk hukum yang sinergis. Berdasarkan fakta-fakta tersebut, maka kajian mengenai hubungan antar Nelayan Jepara dan Karimunjawa dalam pemanfaatan sumberdaya perikanan di Karimunjawa menjadi menarik untuk diteliti.

\section{Pertanyaan Penelitian}

Berdasarkan latar belakang tersebut maka dirumuskan beberapa masalah diteliti, yaitu:

1. Bagaimana pengelolaan sumberdaya perikanan yang dilakukan oleh Pemerintah Daerah Jepara dan Balai Taman Nasional Karimunjawa di Sekitar Taman Nasional Karimunjawa?

2. Bagaimana modal sosial menyambung Nelayan Jepara dan Karimunjawa dalam memanfaatkan sumberdaya perikanan di sekitar Taman Nasional Karimunjawa?

3. Bagaimana hubungan antara modal sosial menyambung dengan persepsi konflik antara Nelayan Jepara dan Karimunjawa dalam memanfaatkan sumberdaya perikanan di Sekitar Taman Nasional Karimunjawa?

\section{Tujuan Penelitian}

Penelitian ini dilakukan di dua tempat yaitu Desa Karimunjawa dan Kabupaten Jepara, Propinsi Jawa Tengah. Pendekatan yang digunakan dalam penelitian ini adalah explanatory research, yaitu untuk menguji hubungan antar variabel yang dihipotesiskan. Sementara strategi penelitian yang digunakan adalah studi kasus yaitu suatu strategi penelitian multi-metode, lazimnya memadukan teknik pengamatan, wawancara, dan analisis dokumen (Sitorus 1998). Populasi dari penelitian ini adalah Nelayan Karimunjawa dan Nelayan Jepara. Unit dari penelitian ini adalah individu yaitu nelayan Desa Karimunjawa dan nelayan Desa Ujungbatu, Kecamatan Jepara yang memanfaatkan sumberdaya perikanan di sekitar Taman Nasional Karimunjawa. Penentuan responden dilakukan dengan menggunakan teknik aksidental stratifikasi yang didasarkan pada kemudahan untuk ditemui Sampel yang terpilih karena berada pada waktu, situasi dan tempat yang tepat (Prasetyo dan Jannah 2005).

\section{HASIL DAN PEMBAHASAN}

\section{Gambaran Lokasi Penelitian}

Taman Nasional Karimunjawa (TNKJ) secara geografis terletak pada koordinat 5040'39'-5055'00" LS dan 110005'57'-110031'15" BT. Karimunjawa ditetapkan sebagai Cagar Alam Laut Karimunjawa sesuai SK Menhut No.123/Kpts-II/1986. Tingginya kepentingan berbagai sektor mendorong perubahan fungsi Karimunjawa dari Cagar Alam menjadi TNKJ. Berdasarkan Surat Keputusan Menteri Kehutanan dan Perkebunan No. 78/ Kpts-II/1999, Cagar Alam Karimunjawa dan sekitarnya yang terletak di Kabupaten Dati II Jepara Provinsi Dati I Jawa Tengah ditetapkan menjadi Taman Nasional dengan nama TNKJ. Mayoritas masyarakat Karimunjawa bekerja sebagai nelayan dan pembudidaya ikan. Desa Ujungbatu merupakan salah satu desa yang berada di Kecamatan Jepara. Desa Ujungbatu memiliki tipografi berupa persisir atau tepi laut dengan ketinggian wilayah kurang dari lima ratus meter. Hampir setengah penduduk Desa Ujungbatu yang bekerja sebagai nelayan. Kondisi geografis Desa Ujungbatu yang berbatasan dengan Laut Jawa menjadi salah satu faktor pendukung banyaknya masyarakat Desa 
Ujungbatu berprofesi sebagai nelayan.

\section{Pengelolaan Sumberdaya Perikanan di Karimunjawa dan Jepara}

Pihak-pihak yang berkepentingan memanfaatkan sumberdaya perikanan di Karimunjawa yaitu, Nelayan Karimunjawa, Nelayan luar Karimunjawa, Pemerintah Kabupaten Jepara, Pemerintah Desa Karimunjawa, dan Departemen Perikanan dan Kelautan. Pengelolaan perikanan oleh berbagai aktor di TNJ dapat dilihat pada Tabel 1.

Tabel 1. Pengelolaan Sumberdaya Perikanan yang Dilakukan oleh Berbagai Aktor di Karimunjawa

\begin{tabular}{|c|c|c|c|}
\hline $\begin{array}{l}\text { Kategori } \\
\text { peraturan } \\
\text { pengelolaan }\end{array}$ & BTNKJ & $\begin{array}{l}\text { Desa Karim- } \\
\text { unjawa }\end{array}$ & $\begin{array}{l}\text { Dinas Ke- } \\
\text { lautan dan } \\
\text { Perikanan }\end{array}$ \\
\hline $\begin{array}{ll}\text { Alat } & \text { Tang- } \\
\text { kap } & \text { yang } \\
\text { dapat } & \text { digu- } \\
\text { nakan } & \end{array}$ & $\begin{array}{l}\text { Alat tang- } \\
\text { kap tra- } \\
\text { dis i o n a } 1 \\
\text { yang ramah } \\
\text { lingkungan. } \\
\text { Alat tang- } \\
\text { kap yang } \\
\text { tidak ra- } \\
\text { mah seperti } \\
\text { mour a mi, } \\
\text { jaring poco- } \\
\text { ng, cantrang } \\
\text { dan sianida } \\
\text { dilarang }\end{array}$ & $\begin{array}{l}\text { Kompresor } \\
\text { dan pancing. } \\
\text { Kompresor } \\
\text { tidak boleh } \\
\text { menggang- } \\
\text { gu pancing. } \\
\text { Pot a s i u m } \\
\text { dilarang. }\end{array}$ & $\begin{array}{l}\text { Semua alat } \\
\mathrm{t} \text { a } \mathrm{n} \text { g k a } \mathrm{p} \\
\text { yang ra- } \\
\text { mah dengan } \\
\text { lingkungan } \\
\text { dan dis- } \\
\text { e s u a i k a n } \\
\text { d e } \mathrm{n} \text { g a n } \\
\text { jalur-jalur } \\
\text { p e n a n g- } \\
\text { kapannya. } \\
\text { Pancing dan } \\
\text { panah }\end{array}$ \\
\hline $\begin{array}{l}\text { W i l a y a h } \\
\text { Tangkap }\end{array}$ & $\begin{array}{l}\text { Zona Tr- } \\
\text { a dis i o n a } 1 \\
\text { perikanan, } \\
\text { kecuali zona } \\
\text { inti, per- } \\
\text { lindungan } \\
\text { bahari dan } \\
\text { rehabilitasi. }\end{array}$ & $\begin{array}{l}\text { Di seluruh } \\
\text { kawasan kec- } \\
\text { uali zona inti. }\end{array}$ & $\begin{array}{l}\text { Jalur-jalur } \\
\text { penangka- } \\
\text { pan. }\end{array}$ \\
\hline Sanksi & $\begin{array}{l}\text { Penjara atau } \\
\text { pidana ku- } \\
\text { rungan dan } \\
\text { denda beru- } \\
\text { pa uang pal- } \\
\text { ing banyak } \\
\text { seratus juta } \\
\text { rupah. }\end{array}$ & $\begin{array}{l}\text { Denda se- } \\
\text { besar dua } \\
\text { juta rupiah } \\
\text { sampai den- } \\
\text { gan lima juta } \\
\text { rupiah dan } \\
\text { membuat su- } \\
\text { rat pernyata- } \\
\text { an. }\end{array}$ & $\begin{array}{l}\text { Denda pal- } \\
\text { ing banyak } \\
\text { dua ratus } \\
\text { lima puluh } \\
\text { juta rupiah. }\end{array}$ \\
\hline
\end{tabular}

Pengelolaan sumberdaya perikanan di Jepara lebih sederhana dibandingkan dengan TNKJ. Sumberdaya di Jepara hanya diatur oleh nelayan Jepara dan Dinas Kelautan dan Perikanan Kecamatan Jepara. Pengelolaan sumberdaya yang dilakukan oleh nelayan Jepara yaitu dengan menetapkan peraturan tidak tertulis antara nelayan Jepara dengan nelayan lain. Peraturan tidak tertulis tersebut merupakan bentuk kesepakatan antara nelayan Jepara dengan nelayan yang memiliki alat tangkap yang berbeda. Pengelolaan oleh Departemen Kelautan dan Perikanan dilakukan berdasarkan peraturan yang telah ditetapkan dari pusat yaitu Peraturan Menteri dan Undang-Undang. Peraturan menteri yang berlaku dalam mengelola sumberdaya perikanan baik di Jepara maupun di
Karimunjawa sama yaitu Peraturan Menteri Kelautan dan Perikanan Nomor Per.02/Men/2011. Peraturan tersebut mengatur tentang jalur penangkapan ikan dan penempatan alat penangkapan ikan dan alat bantu penangkapan ikan di wilayah pengelolaan perikanan Negara Republik Indonesia.

Pengelolaan sumberdaya perikanan di TNKJ dan Jepara yang dilakukan oleh berbagai aktor belum berjalan secara efisien. Peraturan yang ditetapkan oleh berbagai aktor belum dapat diaplikasikan oleh pihak-pihak yang terlibat dalam memanfaatkan sumberdaya perikanan. Hal ini terbukti dengan masih adanya pelanggaran-pelanggaran dalam memanfaatkan sumberdaya perikanan seperti pelanggaran terhadap batas wilayah pemanfaatan dan penggunaan alat tangkap. Pelaksanaan peraturan yang tidak berjalan secara efisen ini disebabkan oleh beberapa faktor, yaitu Pertama, kurangnya sosialisasi peraturan yang dilakukan oleh pemerintah maupun pihak-pihak yang menetapkan peraturan sehingga pengetahuan masyarakat terhadap peraturan mini. Kedua, keinginan masyarakat untuk melakukan peraturan yang sudah ditetapkan juga rendah. Ketika diperhadapkan antara memenuhi kebutuhan hidup dan mematuhi peraturan, maka masyarakat akan lebih memilih memenuhi kebutuhan hidup sekali pun harus melanggar peraturan. Ketiga, penegakan hukum yang lemah. Sosialisasi yang rendah dan keinginan masyarakat yang rendah untuk mematuhi peraturan dapat diatasi

Pemanfaatan Sumberdaya Perikanan oleh Nelayan Karimunjawa dan Nelayan Jepara

Tabel 2. Frekuensi dan persentase responden pedagang makanan di Jalan Babakan berdasarkan status perkawinan, tahun 2012

\begin{tabular}{|c|c|c|}
\hline Kategori & $\begin{array}{l}\text { Nelayan Karimun- } \\
\text { jawa }\end{array}$ & Nelayan Jepara \\
\hline $\begin{array}{l}\text { Penggolongan } \\
\text { nelayan }\end{array}$ & $\begin{array}{l}\text { nelayan tradisional } \\
\text { dan post-tradisional. } \\
\text { Berdasarkan waku } \\
\text { untuk melakukan } \\
\text { operasi penangka- } \\
\text { pan ikan merupakan } \\
\text { nelayan ikan penuh } \\
\text { dan nelayan ikan } \\
\text { sambilan. }\end{array}$ & $\begin{array}{l}\text { c o m m e r c i a l } \\
\text { fisher. Ber- } \\
\text { dasarkan waku } \\
\text { untuk melaku- } \\
\text { kan operasi } \\
\text { penangkapan } \\
\text { ikan merupa- } \\
\text { kan nelayan } \\
\text { ikan penuh. }\end{array}$ \\
\hline
\end{tabular}

Alat tangkap Kompresor, panc- Mini purse ing, bubu, branjang, seine, pukat jaring, dan budidaya harimau dan perikanan. Mayor- pancing. Mayitas menggunakan oritas mengpancing. gunakan mini purse seine.

Status nelayan

Mayoritas pemilik May orita s kapal pemilik ABK

Anggota kelompok

Moyoritas sendiri

Mayoritas dengan teman penangkapan ikan

Kapal menangkap ikan

Daerah penang- Di TNKJ kapan ikan

Di atas 5 GT

Nelayan Karimunjawa dan nelayan Jepara memiliki perbedaan dari segi penggolongan nelayan, alat tangkap yang digunakan, status nelayan, anggota kelompok dalam 
kegiatan penangkapan ikan, kapal menangkap ikan dan daerah penangkapan ikan. Tabel 2 menunjukkan bagaimana perbedaan antara nelayan Karimunjawa dan Jepara dalam memanfaatkan sumberdaya perikanan.

\section{Modal Sosial Menyambung (Bridging Social Capital) Nelayan Karimunjawa dan Nelayan Jepara}

Modal sosial menyambung dapat dianalisis melalui jaringan kerja di luar komunitas, partisipasi dan keanggotaan kelompok di luar komunitas, dan tingkat kepercayaan. Terdapat perbedaan antara modal sosial menyambung di nelayan Karimunjawa dengan nelayan di Jepara. Tabel 3 menyajikan modal sosial menyambung yang dimiliki nelayan Karimunjawa dan nelayan Jepara.

Tabel 3. Modal Sosial Menyambung yang Dimiliki Nelayan Karimunjawa dan Nelayan Jepara

\begin{tabular}{lll}
\hline $\begin{array}{l}\text { Modal Sosial Menyam- } \\
\text { bung }\end{array}$ & $\begin{array}{l}\text { Nelayan Karimun- } \\
\text { jawa }\end{array}$ & $\begin{array}{l}\text { Nelayan } \\
\text { Jepara }\end{array}$ \\
\hline $\begin{array}{l}\text { Jaringan kerja di luar } \\
\text { komunitas }\end{array}$ & Rendah & Rendah \\
$\begin{array}{l}\text { Tingkat partisipasi dan } \\
\text { keanggotaan kelompok } \\
\text { di luar komunitas }\end{array}$ & Rendah & Rendah \\
Tingkat Kepercayaan & Rendah & Tinggi \\
\hline
\end{tabular}

Tingkat jaringan kerja di luar komunitas di Karimunjawa yang rendah dapat disebabkan oleh beberapa faktor. Pertama, Nelayan Karimunjawa hanya memiliki saudara dan teman dari Karimunjawa. Nelayan Karimunjawa adalah nelayan pendatang yang datang dari Jepara, Sulawesi dan berbagai tempat lain kemudian menetap dan menjadi warga Karimunjawa. Setelah bertahun-tahun berada di Karimunjawa akhirnya nelayan tersebut semakin bertambah banyak dan membentuk perkampungan di Karimunjawa. Anak-anak yang dilahirkan dan bertumbuh di Karimunjawa akhirnya memiliki keluarga dan kerabat yang berada di Karimunjawa juga.

Kedua, Kekayaan sumberdaya alam perikanan di Karimunjawa yang melimpah yang menyebabkan nelayan Karimunjawa selalu berkecukupan walaupun hanya melakukan penangkapan ikan di sekitar Karimunjawa. Ketiga, Kapal yang digunakan nelayan Karimunjawa masih sederhana hanya berupa motor tempel atau sampan. Jenis kapal yang sederhana mengakibatkan jarak wilayah tangkap nelayan hanya beberapa mil dalam TNKJ. Hal ini mengakibatkan mobilisasi nelayan Karimunjawa tidak begitu luas, hanya berada di sekitar TNKJ.

Tingkat keanggotaan Nelayan Karimunjawa pada organisasi yang menghubungkan dengan Nelayan Jepara dapat dikatakan rendah. Ada beberapa faktor yang menyebabkan terjadinya kondisi tersebut. Pertama, Nelayan Karimunjawa pada umumnya hampir setiap hari melaut kecuali pada waktu-waktu tertentu seperti hari jumat, gelombang besar dan terang bulan. Banyak persiapan yang harus dilakukan oleh nelayan sebelum melakukan operasi penangkapan ikan. Sangat sedikit waktu yang dimiliki untuk ikut serta dalam kegiatan-kegiatan pertemuan atau keorganisasian. Kedua, keanggotaan dalam organisasi di Karimunjawa belum terdistribusi secara merata. Ketua organisasi umumnya lebih memprioritaskan anggota keluarga atau teman-teman yang terdekat. Ketiga, organisasi Perhimpunan Nelayan atau HNSI yang sudah tidak berjalan.

Tingkat Kepercayaan Nelayan Karimunjawa tergolong rendah disebabkan oleh beberapa faktor. Pertama, perbedaan alat tangkap antara nelayan Karimunjawa dan Nelayan Jepara mengakibatkan nelayan Karimunjawa menganggap bahwa nelayan Jepara sebagai saingan dalam melakukan penangkapan ikan di TNKJ. Kedua, pengalaman nelayan Karimunjawa yang kurang baik dengan nelayan luar komunitas lain mengakibatkan nelayan Karimunjawa lebih berhati-hati terhadap nelayan lain. Tabel 4 menunjukkan persentase modal sosial menyambung yang dimiliki oleh Nelayan Karimunjawa.

Tabel 4. Persentasse Berdasarkan Modal Sosial Menyambung Nelayan Karimunjawa, Kecamatan Karimunjawa Tahun 2012

\begin{tabular}{lll}
\hline \multirow{2}{*}{$\begin{array}{l}\text { Modal sosial menyam- } \\
\text { bung }\end{array}$} & \multicolumn{2}{l}{ Persentase Responden } \\
\cline { 2 - 3 } & Tinggi & Rendah \\
\hline $\begin{array}{l}\text { Jaringan kerja di luar } \\
\text { komunitas }\end{array}$ & $33 \%$ & $67 \%$ \\
$\begin{array}{l}\text { Tingkat partisipasi dan } \\
\text { keanggotaan kelompok } \\
\text { di luar komunitas }\end{array}$ & $7 \%$ & $93 \%$ \\
Tingkat Kepercayaan & $7 \%$ & $93 \%$ \\
\hline
\end{tabular}

Kekuatan jaringan kerja antara nelayan Jepara dengan Karimunjawa tergolong rendah. Hal ini disebabkan karena Nelayan Jepara pada umumnya tidak memiliki saudara atau teman di Karimunjawa. Sehingga hubungan antara nelayan Karimunjawa dengan nelayan Jepara hanya terjadi ketika nelayan Jepara dan Karimunjawa memanfaatkan sumberdaya perikanan di wilayah tangkap yang sama.

Tingkat partisipasi dan keanggotaan Nelayan Jepara dalam kelompok di luar komunitas nelayan tergolong rendah. Tingkat partisipasi dan keanggotaan Nelayan Jepara dalam organisasi di luar komunitas nelayan karena mereka lebih berfokus dengan organisasi nelayan yang terdapat di Ujungbatu. Sementara, organisasi nelayan yang berada di Ujungbatu sangat jarang bekerjasama dengan organisasi nelayan yang berada di luar komunitas nelayan.

Tingkat kepercayaan nelayan Jepara kepada nelayan Karimunjawa tergolong tinggi disebabkan oleh beberapa faktor. Pertama, Nelayan Jepara lebih terbuka dibandingkan dengan nelayan Karimunjawa. Nelayan Jepara sudah terbiasa dengan nelayan komunitas lain. Nelayan Jepara sudah terbiasa berkerja dalam satu kapal dengan nelayan dari Demak. Oleh karena itu, nelayan Jepara lebih bersikap toleran dan dapat menerima komunitas lain.

Kedua, alat tangkap nelayan Karimunjawa yang lebih sederhana dibandingkan dengan nelayan Jepara yang mengakibatkan nelayan Jepara tidak mempermasalahkan apabila nelayan Karimunjawa menangkap ikan di Jepara. Nelayan Jepara mengganggap nelayan Karimunjawa sebagai rekan kerja sesama nelayan ketika melakukan operasi penangkapan ikan. Nelayan Jepara tidak menjadikan nelayan Karimunjawa sebagai saingan. Tabel 5 memperlihatkan persentase modal sosial menyambung yang dimiliki oleh nelayan Jepara. 
Tabel 5. Persentase Berdasarkan Modal Sosial Menyambung Nelayan Ujungbatu, Kecamatan Jepara Tahun 2012

\begin{tabular}{lll}
\hline $\begin{array}{l}\text { Modal sosial men- } \\
\text { yambung }\end{array}$ & \multicolumn{2}{l}{ Persentase Responden } \\
\cline { 2 - 3 } & Tinggi & Rendah \\
\hline $\begin{array}{l}\text { Jaringan kerja di luar } \\
\text { komunitas }\end{array}$ & $13 \%$ & $87 \%$ \\
$\begin{array}{l}\text { Tingkat partisipa- } \\
\text { si dan keanggotaan }\end{array}$ & \\
kelompok di luar ko- \\
munitas
\end{tabular}

Konflik yang terjadi di dalam kehidupan nelayan dapat berupa perkelahian yang melibatkan benturan fisik atau ketidaksukaan terhadap kelompok tertentu. Konflik yang terjadi antara nelayan Karimunjawa dengan nelayan Jepara tergolong konflik kelas. Konflik yang disebabkan perebutan wilayah penangkapan yaitu di daerah TNKJ dan terdapat kesenjangan dalam teknologi penangkapan ikan. Konflik yang terjadi antara nelayan Karimunjawa dan Jepara dapat dilihat dari persepsi nelayan terhadap konflik yang tinggi. Persepsi konflik nelayan Karimunjawa dan Jepara di TNKJ tergolong tinggi. Tabel 6 memperlihatkan jumlah dan persentase persepsi konflik Nelayan Karimunjawa dan Nelayan Jepara. Tingginya persepsi konfik dalam nelayan disebabkan oleh banyaknya pengalaman kejadian konflik yang dialami seperti pencekalan, perusakan alat tangkap bahkan perusakan kapal yang dilakukan oleh Nelayan Karimunjawa terhadap Nelayan Jepara.

Tabel 6. Jumlah dan Persentase Berdasarkan Persepsi Nelayan Karimunjawa dan Nelayan Jepara Terhadap Konflik Tahun 2012.

\begin{tabular}{lllll}
\hline \begin{tabular}{l} 
P e r s e p s i $\begin{array}{l}\text { kelayan Karimun- } \\
\text { konflik }\end{array}$ \\
\cline { 2 - 5 }
\end{tabular} & $\begin{array}{l}\text { Jum- } \\
\text { jawa }\end{array}$ & Persentase & Jumlah & $\begin{array}{l}\text { Persen- } \\
\text { lahe }\end{array}$ \\
\hline Tinggi & 27 & $90 \%$ & 22 & $73 \%$ \\
Rendah & 3 & $10 \%$ & 8 & $27 \%$ \\
Total & 30 & $100 \%$ & 30 & $100 \%$ \\
\hline
\end{tabular}

Hubungan Modal Sosial Menyambung dengan Persepsi Konflik Antara Nelayan Karimunjawa dengan Nelayan Jepara dalam Memanfaatkan Sumberdaya Perikanan di Taman Nasional Karimunjawa

Hasil analisis data pada kasus Karimunjawa menunjukkan terdapat hubungan antara modal sosial menyambung dengan persepsi konflik. Hubungan antara jaringan di luar komunitas, partisipasi dan keanggotaan kelompok di luar komunitas, dan tingkat kepercayaan dengan persepsi konflik merupakan hubungan yang berbanding terbalik. Semakin tinggi jaringan kerja di luar komunitas, partisipasi dan keanggotaan kelompok di luar komunitas, dan tingkat kepercayaan mengakibatkan rendahnya persepsi konflik yang terjadi dan semakin rendah jaringan kerja di luar komunitas, partisipasi dan keanggotaan kelompok di luar komunitas, dan tingkat kepercayaan mengakibatkan semakin tinggi persepsi konflik yang terjadi.

Hasil analisis data pada kasus di Jepara menunjukkan modal sosial berupa hubungan antara jaringan di luar komunitas dan partisipasi dan keanggotaan kelompok di luar komunitas berhubungan dengan persepsi konflik. Hubungan antara jaringan di luar komunitas dan partisipasi dan keanggotaan kelompok di luar komunitas dengan persepsi konflik merupakan hubungan yang berbanding terbalik. Semakin tinggi jaringan kerja di luar komunitas dan partisipasi dan keanggotaan kelompok di luar komunitas mengakibatkan rendahnya persepsi konflik yang terjadi dan semakin rendah jaringan kerja di luar komunitas dan partisipasi dan keanggotaan kelompok di luar komunitas mengakibatkan semakin tinggi persepsi konflik yang terjadi. Berbeda dengan tingkat kepercayaan, pada nelayan Jepara sekali pun tingkat kepercayaan tinggi akan tetapi persepsi konflik yang terjadi juga tinggi.

\section{KESIMPULAN DAN SARAN}

\section{Kesimpulan}

Pengelolaan sumberdaya perikanan yang dilakukan di Karimunjawa berbeda dengan pengelolaan perikanan yang dilakukan di Jepara. Pengelolaan perikanan yang dilakukan di Karimunjawa dilakukan oleh beberapa aktor yaitu, Balai Taman Nasional dengan menetapkan sistem zonasi, Dinas Kelautan dan Perikanan dengan menetapkan peraturan jalur tangkap, Pemerintah Kabupaten Jepara sesuai dengan Surat Keputusan Gubernur dan kearifan lokal yang merupakan hasil kesepakatan yang dibuat oleh pemerintah desa dengan masyarakat. Pengelolaan sumberdaya perikanan di Karimunjawa bersifat kolaboratif karena masyarakat juga memiliki hak mengelola. Masyarakat turut serta dalam menetapkan peraturan pengelolaan sumberdaya perikanan di Karimunjawa. Nelayan Jepara hanya memiliki hak pemanfaatan yaitu menggunakan dan mengambil manfaat sumberdaya perikanan di Jepara. Peraturan pengelolaan pemanfaatan sumberdaya perikanan di Jepara bersifat terpusat. Dinas kelautan dan perikanan yang menetapkan sistem pengelolaan perikanan melalui jalur-jalur penangkapan. Penetapan pembagian wilayah yang dilakukan oleh berbagai aktor dalam pemanfaatan sumberdaya perikanan belum berjalan secara efisien. Hal ini disebabkan oleh karena rendahnya pengetahuan dan kesadaran masyarakat terhadap peraturan tersebut dan penegakan hukum (law enforcement) lemah.

Modal sosial menyambung (bridging social capital) dapat diukur dengan menggunakan variabel jaringan kerja di luar komunitas, tingkat partisipasi dan keanggotaan dalam organisasi di luarkomunitas, dan tingkatkepercayaan. Modal sosial menyambung di Karimunjawa dapat digolongkan rendah. Jaringan kerja, tingkat partisipasi dan keanggotaan dalam organisasi dan tingkat kepercayaan nelayan Karimunjawa terhadap nelayan Jepara rendah. Modal sosial menyambung di Jepara dapat digolongkan rendah. Jaringan kerja, tingkat partisipasi dan keanggotaan dalam organisasi nelayan Jepara dengan nelayan Karimunjawa rendah. Tetapi, berbeda dengan nelayan Karimunjawa, nelayan Jepara memeiliki tingkat kepercayaan yang tinggi terhadap nelayan Karimunjawa. Hal ini disebabkan karena nelayan Jepara tidak merasa terancam atau terganggu dengan keberadaan nelayan Karimunjawa. Nelayan Jepara dalam melakukan operasi penangkapan ikan membutuhkan banyak tenaga kerja. Tenaga kerja nelayan Jepara berasal 
dari berbagai latar belakang kebudayaan dan daerah. Nelayan Jepara sudah terbiasa dengan adanya perbedaan sehingga menjadi lebih tebuka dan mudah menerima orang lain.

Hubungan yang tercipta antara nelayan Karimunjawa dengan Nelayan Jepara cenderung konflik. Hal ini dapat dibuktikan dengan Persepsi nelayan Karimunjawa dan nelayan Jepara yang tinggi terhadap persepsi konflik. Rendahnya modal sosial menyambung yang dimiliki oleh nelayan Karimunjawa dan nelayan Jepara mengakibatkan hubungan antara nelayan Karimunjawa dan nelayan Jepara cenderung konflik. Tingkat kepercayaan nelayan Jepara yang tinggi tidak begitu berpengaruh terhadap persepsi konflik. Konflik hanya dapat dihindari apabila terdapat kepercayaan dari dua belah pihak, baik nelayan Karimunjawa maupun nelayan Jepara. Berdasarkan hal ini, maka dapat disimpulkan bahwa modal sosial menyambung memiliki hubungan dengan konflik.

\section{Saran}

Konflik yang tercipta antara nelayan Karimunjawa dengan nelayan Jepara tidak hanya disebabkan oleh kurangnya komunikasi antar nelayan tetapi juga disebabkan oleh adanya sistem yang belum dapat mengatur dengan baik pemanfaatan sumberdaya perikanan di TNKJ. Saran yang dapat disampaikan berdasarkan hasil penelitian ini adalah sebagai berikut:

1. Pentingnya ada aturan-aturan yang jelas mengenai pemanfaatan sumberdaya perikanan mulai dari batas wilayah tangkap, jenis ikan yang dapat ditangkap, alat tangkap, dan sanksi.

2. Perlu diadakan sosialisasi aturan yang sudah ditetapkan kepada setiap pihak yang terkait sehingga setiap pihak dapat mengetahui status dan peranan serta hal-hal apa saja yang dapat dilakukan dan tidak dapat dilakukan dalam memanfaatkan sumberdaya perikanan.

3. Perlu dilakukan penegakan aturan (law enforcement) dengan menempatkan pengawas-pengawas yang berfungsi untuk mengawasi setiap pihak-pihak yang memanfaatkan sumberdaya perikanan agar peraturan yang ditetapkan dapat berjalan sesuai dengan fungsinya.

\section{DAFTAR PUSTAKA}

Hanafri MI. 2009.Hubungan Modal Sosial Dengan Kemiskinan Masyarakat Nelayan Di Desa Panimbang Jaya, Pandeglang. [skripsi]. Bogor [ID]: Institut Pertanian Bogor. 120 hal.

Kinseng RA. 2007. Konflik-Konflik Sumberdaya Alam di Kalangan Nelayan Indonesia.Sodality: Jurnal Transdisiplin Sosiologi, Komunikasi, dan Ekologi Manusia, 01(01): 87-104.

Lawang RZ. 2005. Kapital Sosial dalam Perspektif Sosiologik. Jakarta [ID]: FSIP UI Press. 237 hal.

Prasetyo dan Jannah. 2005. Metode Penelitian Kuantitatif Teori dan Aplikasi. Jakarta [ID]: PT. Raja Grafindo Persada. 272 hal.

Satria A. 2009a. Ekologi Politik Nelayan. Yogyakarta
[ID]: Lkis. 410 hal.

2009b. Pesisir dan laut untuk rakyat. Bogor [ID]: IPB Press. 144 hal.

2002. Pengantar sosiologi masyarakat pesisir. Jakarta [ID]: PT. Pustaka Cidesindo. 130 hal.

Satria A, Umbari A, Fauzi A, Purbayanto A, Sutarto E, Muchsin I, Muflikhati I, Karim M, Saad S, Oktariza W, dan Imran Z. 2002. Menuju Desentralisi Kelautan. Jakarta [ID]: PT. Pustaka Cidesindo. 210 hal.

Sembiring E. 2010. Resolusi Konflik Pengelolaan Taman Nasional Teluk Cenderawasih di Kabupaten Teluk Wondama. [tesis]. Bogor [ID]: Institut Pertanian Bogor. 113 hal.

Singarimbun M dan Effendi S. 1989. Metode Penelitian Survai. Jakarta [ID]: LP3ES. Hal 3-15.

Sitorus MTF. 1998. Penelitian Kualitatif. Bogor [ID]: Kelompok Dokumentasi Ilmu-ilmu Sosial Fakultas Pertanian IPB. 73 hal.

Shaliza F. Dinamika Konflik antar Komunitas dan Transformasi Modal Sosial Studi Kasus Konflik antara Nelayan Parit III dan Melati di Kabupaten Bengkalis, Provinsi Riau. [tesis]. Bogor [ID]: Institut Pertanian Bogor. 160 hal.

Soekanto S. 2002. Sosiologi: suatu pengantar. Jakarta [ID]: Rajawali Press. 296 hal.

Vipriyanti NU. 2007. Studi Sosial Ekonomi Tentang Keterkaitan antara Modal Sosial dan Pembangunan Ekonomi Wilayah Studi Kasus di Empat Kabupaten di Provinsi Bali. [disertasi]. Bogor [ID]: Institut Pertanian Bogor. 241 hal.

Suwartika, R., 2003. Struktur modal usaha dan fungsi modal sosial dalam strategi bertahan hidup pekerja migran di sektor informal (studi kasus Kecamatan Pelabuhan Ratu Dan Kecamatan Cisaat, Kabupaten

Wahyono. 2009. Indonesia Negara Maritim. Jakarta[ID]: Teraju. 212 hal.

Yulidar AR. 2003. Potensi dalam Pemberdayaan Nelayan Modal Sosial Komunitas Nelayan Desa Teluk Labuan, Banten. [tesis]. Bogor [ID]:Institut Pertanian Bogor. 123 hal. 